\title{
Nuclear Magnetic Resonance Characterization of Indonesian Amber ${ }^{1}$
}

\author{
Joseph B. Lambert ${ }^{2}$, Allison J. Levy ${ }^{2}$, Jorge A. Santiago-Blay ${ }^{3}$, and Yuyang $\mathrm{Wu}^{4}$
}

\begin{abstract}
Amber from four major Indonesian islands (Sumatra, Sulawesi, Borneo, New Guinea), Malaysian Borneo, and from the Papua New Guinea island of Vanatinai (a total of 19 samples) has been examined by solid state carbon-13 and solution proton nuclear magnetic resonance (NMR) spectroscopy. All samples but one had common NMR fingerprints by all spectral tests, characteristic of NMR Group B ambers. The single exception, called green copal, had NMR fingerprints very similar to a commercial sample of dammar, the name given to many modern exudates from Dipterocarpaceae trees in the region. There was a clear familial resemblance for the dammar and green copal samples with all the spectra from many samples of modern dipterocarp exudates, with the trend of greater spectral complexity in going from amber to copal/dammar and modern exudates. These spectral comparisons provide further evidence that dipterocarp forests provided the resins that matured into copal and eventually amber after the passage of millions of years.
\end{abstract}

Key Words: amber, Borneo, copal, Dipterocarpaceae, fossilized resin, Indonesia, NMR, nuclear magnetic resonance spectroscopy

Unlike other gemstones, amber is a plant product, which is found worldwide and was formed by fossilization of resins exuded from certain ancient trees (Anderson and Crelling 1995; Fraquet 1987; Grimaldi 2003; Langenheim 2003; Mills and White 1994; Poinar and Poinar 1994). The process is incomplete when the time span is only a few thousand to a million years, and such fossilized resin is called copal. Only when fully fossilized after more than a million years is the material properly called amber. We use this term generally, although it originally was associated with material from the Baltic Sea region. Continued changes occur in deeper time, the overall geological process being called maturation (Lambert et al. 2008). Amber is common from the Miocene to the Cretaceous periods (5 to $150 \mathrm{Ma}$ ) and is known from the Jurassic and Triassic periods (up to $250 \mathrm{Ma}$ ).

Although scientific examination of amber goes back to the nineteenth century, Beck's use of infrared spectroscopy on bulk samples of amber was the

\footnotetext{
${ }^{1}$ Submitted on July 26, 2013. Accepted on August 19, 2013. Final revisions received on September 3, 2013.

${ }^{2}$ Department of Chemistry, Trinity University, One Trinity Place, San Antonio, Texas 78212-1200 USA. E-mail: jlambert@ northwestern.edu

${ }^{3}$ Department of Paleobiology, National Museum of Natural History, Washington, District of Columbia 20560 USA. E-mail: blayj@si.edu

${ }^{4}$ Department of Chemistry, Northwestern University, 2145 Sheridan Road, Evanston, Illinois, 60208-3113 USA. E-mail: y-wu1@ northwestern.edu
}

DOI: 10.9784/LEB1(3)Lambert.02

Electronically available on September 25, 2013. Mailed in October12, 2013. 
first effective approach (Beck 1986). Today, nuclear magnetic resonance (NMR) spectroscopy (Lambert and Frye 1982) and pyrolysis gas chromatography with mass spectrometry (GC/MS) (Anderson and Winans 1991) provide the best approaches to amber characterization. Both methods have distinguished several distinct categories of amber, differing primarily in the botanical nature of the ancient tree source (Lambert et al. 2008). Whereas NMR Group A (MS Class Ib) amber came from gymnosperms (conifers), NMR Group B (MS Class II) amber came from angiosperms (flowering plants). These two classes of amber occur worldwide. The conifer class occurs across North America, Greenland, Western Europe, Southwest Asia, China, Siberia, Southeast Asia, Australia, and New Zealand. The angiosperm class has limited sources in the United States (so far, only in the states of Arkansas and North Carolina), South Asia (the Indian states of Kerala and Meghalaya), Indonesia, Papua New Guinea, and southern Australia. A distinct angiosperm category, termed NMR Group D or MS Class Ic, occurs in Mesoamerica, the Caribbean, South America, Africa, and possibly Yemen. Whereas Group B ambers are thought to derive from the family Dipterocarpaceae, Group D ambers are from the Fabaceae (legumes). The precise conifer source of Group A ambers is still uncertain.

Even though Group B amber occurs worldwide, such materials tend to be much less common than those of Group A. Of the samples studied by carbon-13 $\left({ }^{13} \mathrm{C}\right)$ NMR spectroscopy, a single sample has been examined from Papua New Guinea (NMR sample 139 in our overall numbering system, referred to as sample 20 in the original study, Lambert et al. 1993). It came from Sudest Island, now known as Vanatinai, some 220 miles southeast of the main island of New Guinea. Two Australian samples (called 26 and 32 in the same study, but now overall 145 and 151, Lambert et al. 1993) came from Cape Patterson and from the Wonthoggi Coal Mine (Upper Cretaceous), both in the state of Victoria in southeastern Australia. An Indian sample (374), extracted from the Warkalli formation (upper Tertiary), near Nileshwar on the Kerala (southwestern) coast of India proved to be Group B (Lambert et al. 2012), as did a sample (1011) from the opposite end of India, the northeastern state of Meghalaya near the town of Cherrapunji (Sohra), north of Bangladesh. We have examined three samples $(109,110,170)$ from Malvern, Arkansas (USA), associated with the Claiborne Formation (Lower Middle Eocene, minimum age $50 \mathrm{Ma}$ ), all identified as Group B (Lambert et al. 1990). Amber from North Carolina (USA) exhibits a dichotomy in that closely associated materials may be either Group A or Group B, only distinguishable by NMR or MS methods. We have examined 16 alleged ambers from North Carolina, of which two proved not to be amber (one was a modern pinacean resin and another contained no observable carbon). Of the remaining 14 , four $(253,1259,1261$, and 1479) proved to be Group B, all from Beaufort Co. and associated with phosphate mines. The stratigraphic level has been identified as the Pungo River Formation from the Lower Miocene. 
Group A ambers also come from Beaufort Co., as well as from other NC counties. Geological times for Group B ambers thus range from about 20 to 100 Ma.

Indonesia comprises most of the island mass that lies roughly on a diagonal from Australia to the Southeast Asian mainland. Indonesia is composed of more than 18,000 islands, of which some 900 are inhabited. The main islands (from west to east) are Sumatra, Java, the southern portion of Borneo known as Kalimantan, Sulawesi, and two provinces on the western side of the island of New Guinea, formerly called Irian Jaya (Figure 1). Some of the islands are shared by other countries, including Brunei and two Malaysian states on the north side of Borneo, Papua New Guinea on the eastern half of New Guinea, and East Timor. The Indonesian archipelago is a rich source of both amber and its presumed botanical precursor, often called dammar gum or resin. The fossilized resins are mined from coal and lignite beds dating usually to the Early Miocene (20-23 Ma) and found in numerous locations, including the Talang Akar formation in South Sumatra, the Jampang formation in West Java, West Kalimantan, Sulawesi, and West Papua. Although many Indonesian ambers have the classic colors of European and American amber (yellow to brown), very lightly colored materials are common, tending towards exotic and rare colors such as blue.

We previously have analyzed three samples from this region, as well as the already mentioned sample from Vanatinai, Papua New Guinea. A sample from the Harvard University Farlow Herbarium (Economic Botany General Collection) (NMR number 972) was listed as Borneo copal (country not specified). The ${ }^{13} \mathrm{C}$ NMR spectrum of this material, however, does not resemble any class of amber. It more closely resembles a modern resin from a conifer from the family Araucariaceae. We also analyzed samples referred to only as amber from Malaysian Borneo (157) and amber from Sarawak (167), supplied by George O. Poinar Jr. These materials proved to be Group B ambers.

Indonesian ambers also have been studied with MS methods. Brackman et al. (1984) examined what they called "fossil resin from Miocene coal" from the Bukit Asam region of Sumatra. They reported that the material was formed from sesqui- and triterpenes from trees of the Dipterocarpaceae, the original terpenes having polymerized to resins with molecular weights up to 300,000 . Van Aarssen et al. (1990) reported that fossil resin from Brunei on Borneo exhibited similarities to modern dammar (resin from dipterocarps). They found that the low molecular weight (soluble) fraction contained sesqui- and triterpenes other than the bicadinanes. The high molecular weight (insoluble) fraction was a polymer based on the sesquiterpene cadinene. The exact nature of the polymers, however, has been elusive. Stout (1995), using MS methods, concluded that the polymers from fossil resins from Borneo were not based on polycadinanes common in dammars. Similar results were obtained by Anderson and Muntean (2000). They interpreted their results as being inconsistent with a 


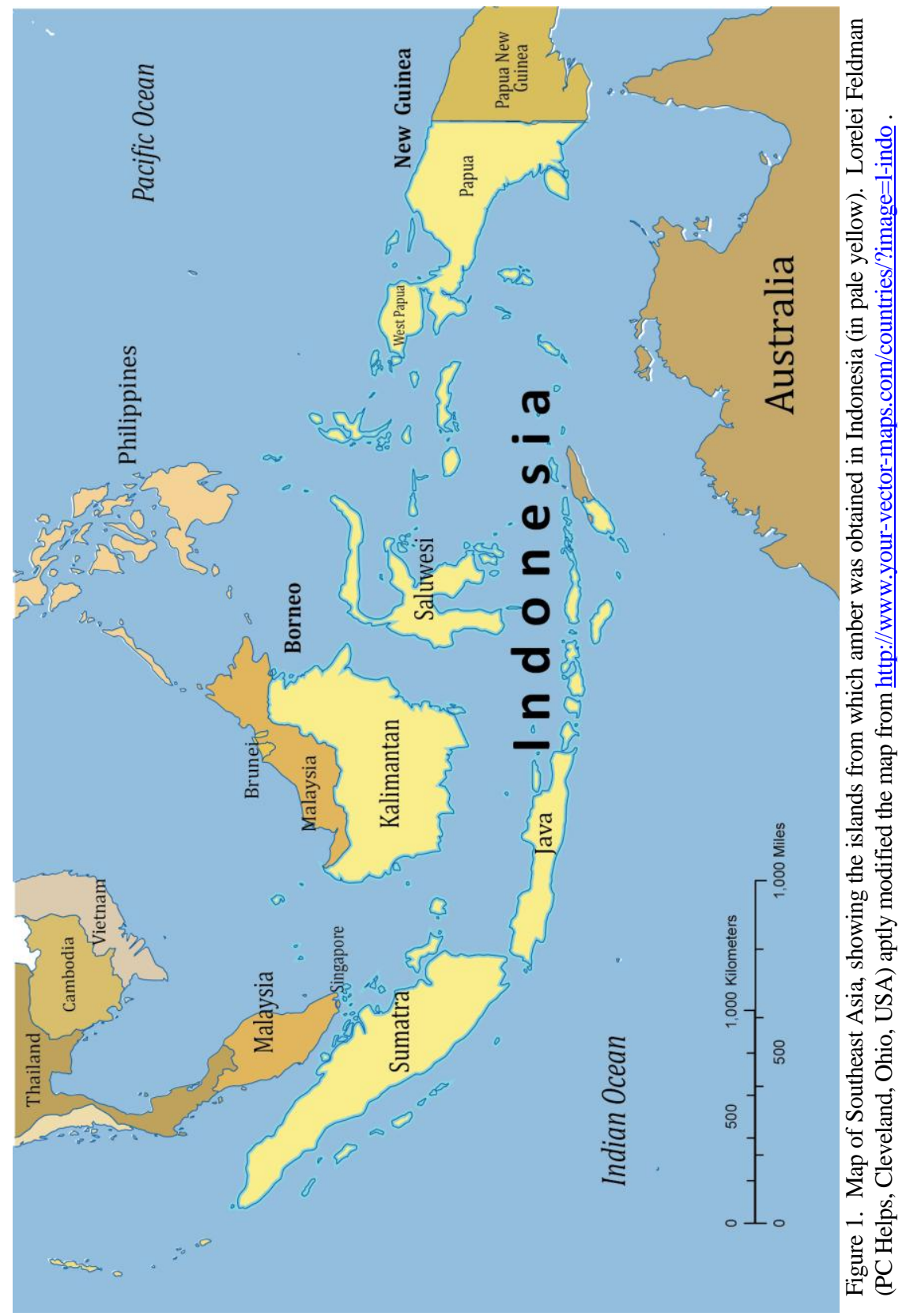


polycadinene structure for the polymer, although they did not propose an alternative. By solution-phase proton $\left({ }^{1} \mathrm{H}\right)$ NMR experiments, they confirmed that the primary alkene present in the fossilized materials was the same as that in modern dammar, supporting the theory that the botanical precursors to the fossilized materials came from the Dipterocarpaceae. Their fossilized sample was from the Merit Pila Coal Mine from the Malaysian state of Sarawak on Borneo.

Modern exudates from this region often are called dammar (or damar) gum or resin. The term gum is inappropriate in a technical context, as it normally refers to an exudate composed entirely of polycarbohydrates (Nussinovich 2010), whereas exudatic resins are composed of terpenes (Langenheim 2003). Indeed, dammar from trees of the Dipterocarpaceae, particularly the genera Shorea and Hopea, are composed of triterpenes such as dammarane, oleanane, and oleanonic acid. Dammar includes, in addition to these low molecular weight molecules, a high molecular weight (polymeric) component.

We report herein the first comprehensive study of amber from the Indonesian archipelago (including countries that share islands) by NMR spectroscopy. For analysis of the material in bulk, we use solid state ${ }^{13} \mathrm{C} \mathrm{NMR}$ spectroscopy. In addition, we examine the same, highly soluble materials in solution by ${ }^{1} \mathrm{H}$ NMR spectroscopy. The two methods provide complementary, independent, phenomenological profiles of the materials. In contrast to GC/MS, with which efforts are made to identify individual molecules out of a host of constituents, NMR spectroscopy provides molecular fingerprints either of the bulk or of the soluble portion. We have obtained 19 samples from the islands of Sumatra, Sulawesi, Borneo, New Guinea, and Vanatinai to make comparisons not previously possible, as earlier studies have focused on just a few samples.

\section{Methods}

Table 1 lists the samples that comprise this study, including their sources. Four types of spectra were taken for each sample. (1) Solid state ${ }^{13} \mathrm{C}$ spectra with normal decoupling. Under these conditions, all protons are decoupled from the ${ }^{13} \mathrm{C}$ nuclei. (2) Solid state ${ }^{13} \mathrm{C}$ spectra with dipolar dephasing (also called interrupted decoupling). An extra ${ }^{1} \mathrm{H}$ delay prevents most protons from being decoupled from ${ }^{13} \mathrm{C}$, so that their resonances become broadened to the point of disappearance. Resonances remain primarily from carbons with no attached protons (quaternary carbons and carbonyl carbons other than aldehydes). Some rapidly moving carbons also produce surviving resonances. (3)The one-dimensional (1D) solution ${ }^{1} \mathrm{H}$ spectrum. (4) The two-dimensional (2D) solution spectrum known as COSY (for COrrelation SpectroscopY), in which the peaks derive from coupling between two protons. Both $\mathrm{x}$ and $\mathrm{y}$ coordinates are the normal ${ }^{1} \mathrm{H}$ chemical shifts. An observed peak then represents coupling between protons resonating at the two coordinates $(x$, $y$ ) of the peak. Detailed interpretation of resonance positions or cross peaks is not needed, as these spectra are used as fingerprints of the materials. Our suite of experiments thus provides four different fingerprints for each sample. 
Table 1. Sources of Indonesian ambers and related materials

\begin{tabular}{|c|c|c|c|}
\hline $\begin{array}{l}\text { Sample } \\
\text { Number }\end{array}$ & Source & Provider & Color \\
\hline 139 & $\begin{array}{l}\text { Sudest Island } \\
\text { (Vanatinai), Papua New } \\
\text { Guinea }\end{array}$ & George O. Poinar Jr. & golden brown \\
\hline 167 & Sumatra, Indonesia & George O. Poinar Jr. & golden brown \\
\hline 1418 & $\begin{array}{l}\text { Kuala Tungkal, Jambi, } \\
\text { Central Sumatra, } \\
\text { Indonesia }\end{array}$ & $\begin{array}{l}\text { Mohammad Iskandar } \\
\text { bin Marzuki }\end{array}$ & $\begin{array}{l}\text { light yellowish } \\
\text { brown }\end{array}$ \\
\hline 1419 & $\begin{array}{l}\text { Kuala Tungkal, Jambi, } \\
\text { Central Sumatra, } \\
\text { Indonesia }\end{array}$ & $\begin{array}{l}\text { Mohammad Iskandar } \\
\text { bin Marzuki }\end{array}$ & $\begin{array}{l}\text { light yellowish } \\
\text { brown }\end{array}$ \\
\hline 1420 & $\begin{array}{l}\text { Padang, West Sumatra, } \\
\text { Indonesia }\end{array}$ & $\begin{array}{l}\text { Mohammad Iskandar } \\
\text { bin Marzuki }\end{array}$ & brownish yellow \\
\hline 1423 & $\begin{array}{l}\text { Lampung, South } \\
\text { Sumatra, Indonesia }\end{array}$ & $\begin{array}{l}\text { Mohammad Iskandar } \\
\text { bin Marzuki }\end{array}$ & $\begin{array}{l}\text { dark yellow with } \\
\text { bluish tinge }\end{array}$ \\
\hline 1424 & $\begin{array}{l}\text { Lampung, South } \\
\text { Sumatra, Indonesia }\end{array}$ & $\begin{array}{l}\text { Mohammad Iskandar } \\
\text { bin Marzuki }\end{array}$ & $\begin{array}{l}\text { clear with greenish } \\
\text { tinge }\end{array}$ \\
\hline 1425 & $\begin{array}{l}\text { Lampung, South } \\
\text { Sumatra, Indonesia }\end{array}$ & $\begin{array}{l}\text { Mohammad Iskandar } \\
\text { bin Marzuki }\end{array}$ & $\begin{array}{l}\text { dark yellowish } \\
\text { brown }\end{array}$ \\
\hline 1437 & $\begin{array}{l}\text { Lampung, South } \\
\text { Sumatra, Indonesia }\end{array}$ & $\begin{array}{l}\text { Teruhisa Ueno, } \\
\text { Fukuoka, Japan }\end{array}$ & $\begin{array}{l}\text { yellow with darker } \\
\text { regions }\end{array}$ \\
\hline 1421 & $\begin{array}{l}\text { Kendari, Southwest } \\
\text { Sulawesi, Indonesia }\end{array}$ & $\begin{array}{l}\text { Mohammad Iskandar } \\
\text { bin Marzuki }\end{array}$ & yellowish brown \\
\hline 1513 & Sulawesi, Indonesia & $\begin{array}{l}\text { Galactic Stone and } \\
\text { Ironworks }\end{array}$ & reddish brown \\
\hline 1422 & $\begin{array}{l}\text { Manokwari, West Papua } \\
\text { (Irian Jaya), Indonesia }\end{array}$ & $\begin{array}{l}\text { Mohammad Iskandar } \\
\text { bin Marzuki }\end{array}$ & $\begin{array}{l}\text { light yellowish } \\
\text { brown }\end{array}$ \\
\hline 1414 & $\begin{array}{l}\text { West Kalimatan } \\
\text { (Borneo), Indonesia }\end{array}$ & $\begin{array}{l}\text { Mohammad Iskandar } \\
\text { bin Marzuki }\end{array}$ & dark orangish red \\
\hline 1415 & $\begin{array}{l}\text { West Kalimatan } \\
\text { (Borneo), Indonesia }\end{array}$ & $\begin{array}{l}\text { Mohammad Iskandar } \\
\text { bin Marzuki }\end{array}$ & opaque gray to $\tan$ \\
\hline 1416 & $\begin{array}{l}\text { Sintang, West Kalimatan } \\
\text { (Borneo), Indonesia }\end{array}$ & $\begin{array}{l}\text { Mohammad Iskandar } \\
\text { bin Marzuki }\end{array}$ & yellowish brown \\
\hline 1417 & $\begin{array}{l}\text { Sintang, West Kalimatan } \\
\text { (Borneo), Indonesia }\end{array}$ & $\begin{array}{l}\text { Mohammad Iskandar } \\
\text { bin Marzuki }\end{array}$ & $\begin{array}{l}\text { light yellowish } \\
\text { brown }\end{array}$ \\
\hline 1453 & $\begin{array}{l}\text { Samandra, Kalimantan } \\
\text { (Borneo), Indonesia }\end{array}$ & A. Brown & brownish orange \\
\hline 157 & Borneo, Malaysia & George O. Poinar Jr. & light yellow \\
\hline 1506 & $\begin{array}{l}\text { Merit Pila, Sarawak, } \\
\text { Borneo, Malaysia }\end{array}$ & $\begin{array}{l}\text { Galactic Stone and } \\
\text { Ironworks }\end{array}$ & dirty yellow \\
\hline 270 & $\begin{array}{l}\text { commercial dammar } \\
\text { (modern) }\end{array}$ & George O. Poinar Jr. & light yellow \\
\hline 789 & $\begin{array}{l}\text { Shorea hopeifolia (Heim) } \\
\text { Sym. (modern) }\end{array}$ & $\begin{array}{l}\text { New York Botanical } \\
\text { Garden; Jorge A. } \\
\text { Santiago-Blay }\end{array}$ & reddish yellow \\
\hline
\end{tabular}


Materials first were ground into a fine powder. For solid state ${ }^{13} \mathrm{C}$ spectra, a minimum of $50 \mathrm{mg}$ was required and a full load was $160 \mathrm{mg}$. Typically at least $100 \mathrm{mg}$ was loaded into a Varian 5-mm, general-purpose Zirconia rotor sealed with Vespel caps. For solution state ${ }^{1} \mathrm{H}$ spectra, approximately $55 \mathrm{mg}$ of powdered amber was transferred to a small, glass vial, and about $1 \mathrm{~mL}$ of deuterated chloroform- $d$ was added to each vial. The supernatant was pipetted out and transferred to a 5-mm NMR tube.

Solid state ${ }^{13} \mathrm{C}$ NMR data were recorded on a $400 \mathrm{MHz}$ Varian NMR System with a 5-mm T3 PENCIL probe. The magic angle spinning (MAS) rate was set to $5000 \mathrm{~Hz}$. The cross polarization (CP) pulse sequence was used for normal proton decoupling. For interrupted decoupling (dipolar dephasing), a 50- $\mu$ s delay was applied in the ${ }^{1} \mathrm{H}$ channel just before the $180^{\circ}$ pulse in the ${ }^{13} \mathrm{C}$ channel. We used adamantane to optimize the Hartmann-Hahn matching conditions for normal $\mathrm{CP}$ experiments and to adjust the observation pulse and the delay time for dipolar dephasing. A typical parameter set was as follows: spectrum frequency $100.544 \mathrm{MHz}$, spectral width $50 \mathrm{kHz}$, pulse width $3.4 \mu$ s for the $90^{\circ}$ pulse for both ${ }^{1} \mathrm{H}$ and ${ }^{13} \mathrm{C}$ nuclei, delay time $5 \mathrm{~s}$, contact time $2 \mathrm{~ms}$, acquisition time $20.5 \mathrm{~ms}$, and scan number 256 . Solid state ${ }^{13} \mathrm{C}$ spectra were referenced to an external adamantane peak at $\delta 38.3$ and were converted to tetramethylsilane at $\delta 0.0$.

Proton spectra were obtained on a Varian Inova-500 NMR spectrometer at room temperature without spinning. Typical one-dimensional parameters were as follows: spectral width $6009.6 \mathrm{~Hz}$, pulse width 45 or $60^{\circ}$, delay time $1.0 \mathrm{~s}$, acquisition time $2.726 \mathrm{~s}$, and scan number 64. Spectra were referenced in $\mathrm{CDCl}_{3}$ to TMS. Typical two-dimensional parameters without pulsed field gradients were as follows: spectral width $6009.6 \mathrm{~Hz}$, pulse width $90^{\circ}$, delay time $1.0 \mathrm{~s}$, scan number 1 , and increment number 128 .

\section{Discussion}

Figure 2 illustrates typical solid state ${ }^{13} \mathrm{C}$ spectra of the Indonesian ambers. This particular piece (no. 1418) was found in Kuala Tungkal, Jambi, Central Sumatra. Its light coloring was dominated by yellows and browns, but the clearest, inner portion had only a bluish tinge. The inner and outer portions were not separated. The saturated (alkane) portion of the ${ }^{13} \mathrm{C}$ spectra with full decoupling (lower spectrum) is dominated by five strong peaks in the saturated region at $\delta 16,22,26,37$, and 48 . These peaks come from methyl, methylene, and methine carbons that are attached to other carbons rather than to heteroatoms (oxygen, nitrogen). The only other significant resonances are the two broad peaks in the alkene region at $\delta 126$ and $135(\mathrm{CH}==\mathrm{CH})$. Peaks in the vicinity of $\delta 80$ and 180 are spinning sidebands of the alkenic peaks. With dipolar dephasing (upper spectrum), three saturated peaks ( $\delta 16,22$, and 37$)$ and one weak alkenic peak survive. This three-peak saturated pattern is particularly 


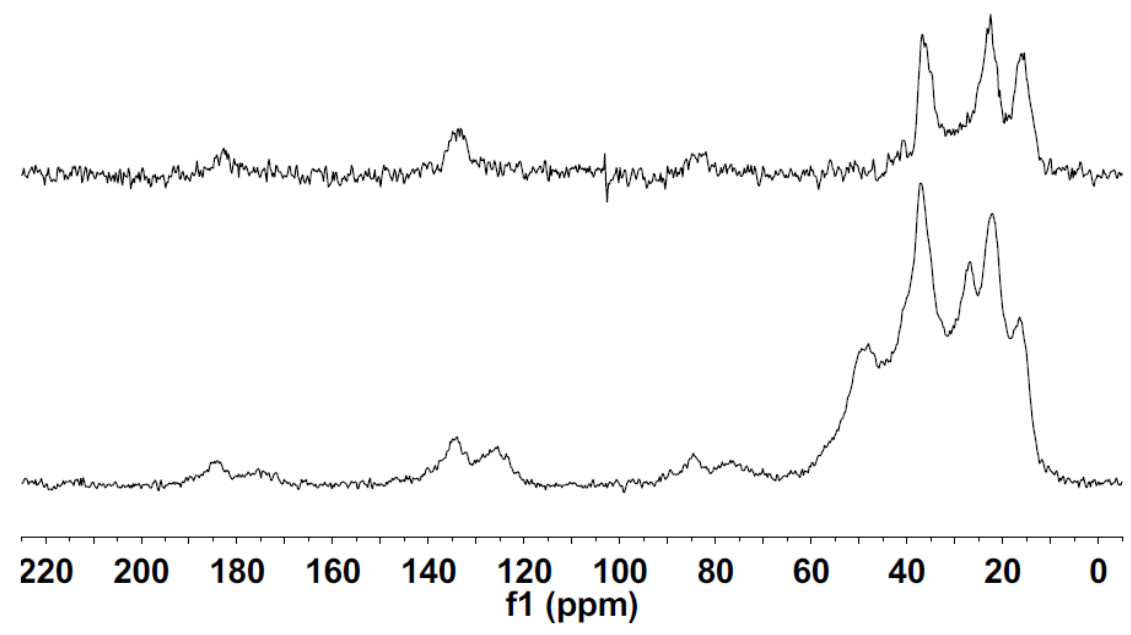

Figure 2. The solid state ${ }^{13} \mathrm{C}$ spectrum of amber from Kuala Tungkal, Jambi, Central Sumatra, Indonesia (sample no. 1418) with normal decoupling (lower) and with dipolar dephasing (upper).

diagnostic for Group B ambers. Amber from Groups A and D give very different patterns (Lambert et al. 2008).

The ${ }^{13} \mathrm{C}$ spectra are devoid of resonances in the carbonyl region $(\delta 160$ 220), so that aldehydes, ketones, esters, and carboxylic acids are absent or below the detectable threshold. Resonances in the alkenic region are limited to peaks between $\delta 120$ and 140. These positions are characteristic of disubstituted double bonds $(-\mathrm{HC}==\mathrm{CH}-$ ), as found along straight chains or within rings. Terminal-chain and unsubstituted-exocyclic alkenes $\left(==\mathrm{CH}_{2}\right)$ resonate at $\delta$ ca. 110 and fully substituted double bonds $(>\mathrm{C}==)$ at $\delta$ ca. 150 , regions that are empty in the spectra.

The 1D solution ${ }^{1} \mathrm{H}$ proton spectrum is equally distinctive (Figure 3). In this illustration from the same amber from Central Sumatra (no. 1418), the sharp peak at $\delta 0.0$ is the standard, tetramethylsilane $\left(\mathrm{Me}_{4} \mathrm{Si}\right)$, and the sharp peak at $\delta$ 7.3 is from the $\mathrm{CHCl}_{3}$ impurity in the deuterated solvent, $\mathrm{CDCl}_{3}$. There are two dominant peaks in the saturated region at $\delta 0.8$ and 0.9. Additional peaks from saturated protons occur from $\delta 1.0$ to 2.2 in a pattern this is repeated by almost all Group B ambers (Lambert et al. 2012). In addition, there are two alkenic peaks at $\delta 5.3$ and 5.5 and very weak aromatic peaks in the vicinity of $\delta$ 7.0. The carbon and proton spectra generally match in functionality. In the 2D COSY spectrum (Figure 4 for the same amber, no. 1418) there is a mass of cross peaks representing coupling between pairs of saturated protons $(\delta 1-3)$ that is of no particular use. The only significant cross peak is found at $(2.2,5.4)$ and 


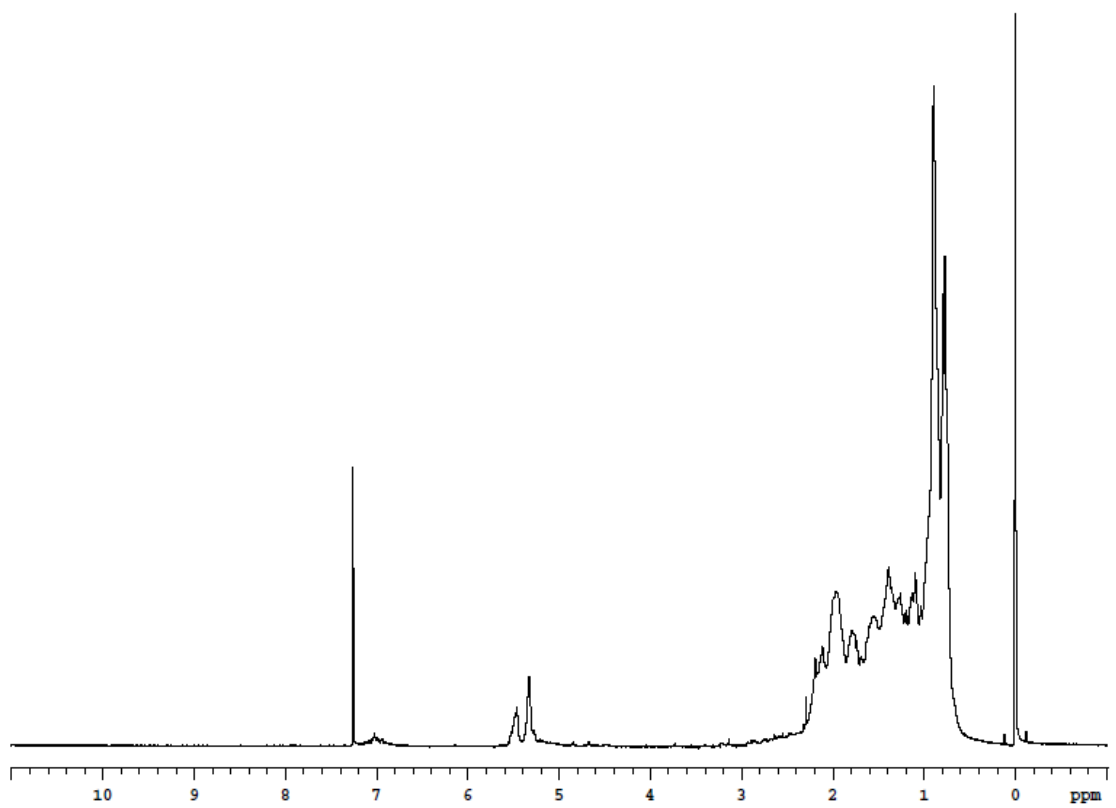

Figure 3. The 1D ${ }^{1} \mathrm{H}$ spectrum of amber from Kuala Tungkal, Jambi, Central Sumatra, Indonesia (sample no. 1418) in chloroform- $d$.

represents coupling between saturated and alkenic protons, as in an allylic fragment, $\mathrm{CH}-\mathrm{CH}==\mathrm{CH}$. Three other cross peaks often found in Group B ambers (Lambert et al. 2008) are present in many samples in this study but are weak.

These carbon and proton patterns are repeated most harmoniously throughout almost all the amber samples from Indonesia, Malaysian Borneo, and Papua New Guinea, irrespective of source island or color. It is apparent that the causes of color in these ambers are not based on organic functionality but more likely on the physical structure (Nassau 1983). Not only are the spectra independent of color, but the spectra do not support extended aromatic or unsaturated systems, which must provide the electronic transitions that are the molecular basis of color. The saturated regions of these spectra closely parallel those previously observed in Type B ambers from Arkansas, North Carolina, Australia, and India, favoring a rather specific botanical source (Lambert et al. 2012). 


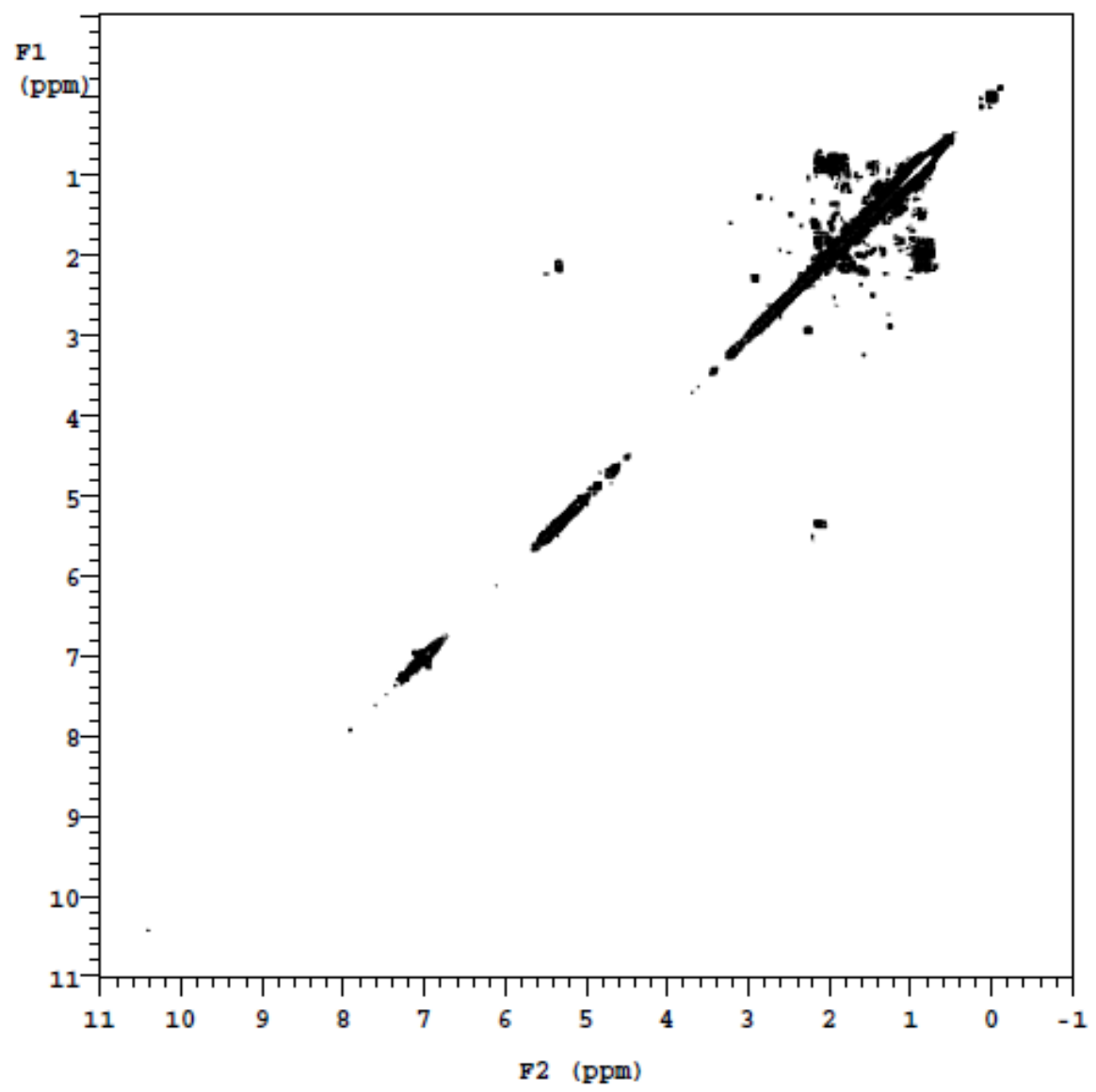

Figure 4. The 2D COSY spectrum of amber from Kuala Tungkal, Jambi, Central Sumatra, Indonesia (sample no. 1418) in chloroform- $d$.

The alkene region contains a pair of peaks at $\delta 5.3$ and 5.5. In all Indonesian samples, the peak at lower frequency $(\delta 5.3)$ is of higher intensity, as in Figure 3. Sample 1506 from Malaysian Borneo exhibits this pattern as well. In contrast, the sample from the Papua New Guinea island (139) and three samples from India $(194,374,1011)$, and a sample from Arkansas (1436) exhibit a higher intensity for the higher frequency peak $(\delta 5.5)$. Thus, there may be distinctions within Group B ambers.

The one spectral exception to the general pattern is sample 1424. This sample is from Lampung, South Sumatra, as are 1423 and 1425. Sample 1424, however, is labeled "green copal gum," whereas the other two are labeled "amber." Samples 1423 and 1425 both are clear but are colored dark yellow to yellowish brown (the traditional amber color). On the other hand, sample 1424 
is clear with a greenish tint. The term "green amber" sometimes is used to mean "young amber," synonymous with copal or immature fossil resin. Commercial amber with an opaque green color is likely to have been dyed artificially. This material (1424), however, is truly a green amber in color as well as lack of maturity. Like other copals from America and Africa that we have studied (Lambert et al. 2002), sample 1424 is quite soft and highly soluble in organic solvents. In his notes on the sample, Iskandar states that the supplier claimed that the "copal is extremely rare, soft like kauri gum, not easy to polish."

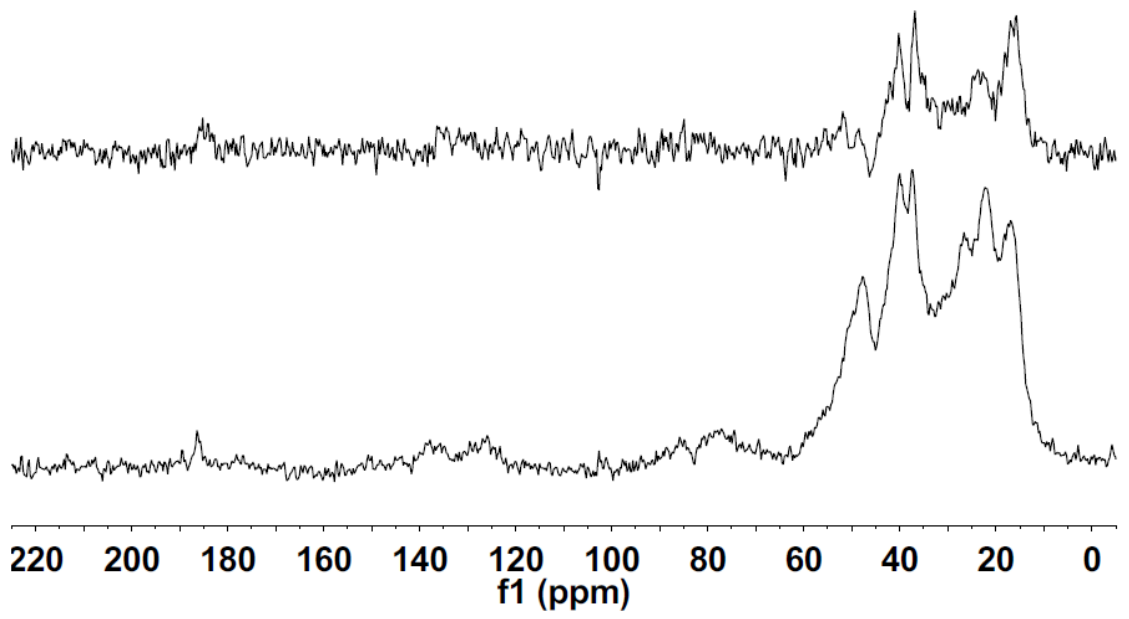

Figure 5. The solid state ${ }^{13} \mathrm{C}$ spectrum of green copal gum from Lampung, South Sumatra, Indonesia (sample no. 1424) with normal decoupling (lower) and with dipolar dephasing (upper).

Figure 5 (above) provides the ${ }^{13} \mathrm{C}$ spectra of sample 1424. At first glance, the appearance is not appreciably different from the other 18 samples. The most noticeable difference is the fact the strongest peak at $\delta 37$ has been replaced by two peaks at $\delta 37$ and 40 (really, the addition of a new peak). In addition, in the alkane region the peaks at $\delta 17$ and 27 have gained in intensity on the peak at $\delta$ 23. The spectrum with dipolar dephasing mirrors these changes. The peak at $\delta$ 16 is stronger and that at $\delta 23$ is much reduced. The peak at $\delta 37$ has been joined by a new one at $\delta 40$. More striking differences are seen in the ${ }^{1} \mathrm{H}$ spectra. The 1D spectrum (Figure 6) is much richer in fine structure than all the other spectra (compare Figure 3). One of the alkenic peaks found in the Indonesian ambers still occurs at $\delta 5.5$, but the peak at $\delta 5.3$ is quite weak. This pattern represents the same reversal in intensity found in the ambers from India, in comparison with those seen in all the Indonesian ambers. The entire alkenic 


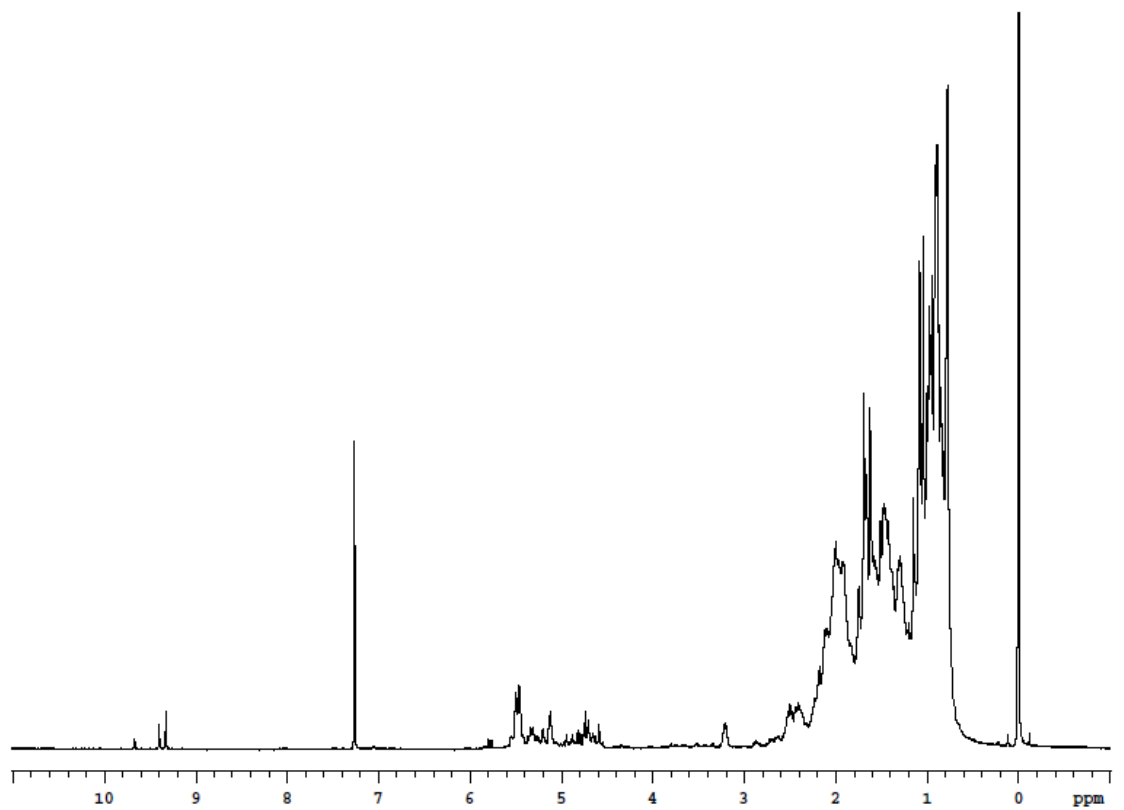

Figure 6. The 1D ${ }^{1} \mathrm{H}$ spectrum of green copal gum from Lampung, South Sumatra, Indonesia (sample no. 1424) in chloroform- $d$.

region from $\delta 4.6$ to 5.8 now is rich with small, sharp peaks. The aromatic region is entirely empty, but several peaks have appeared in the aldehydic region, $\delta 9-10$. Although the overall gestalt of the saturated region is very similar in Figure 6 to that in the ambers (Figure 3), the region is richer and the peaks sharper. The two peaks at $\delta$ 0.8-1.0 in Figure 3 have been replaced by a dozen or so in Figure 6. There still is a significant peak at $\delta 2.0$ but with more fine structure. There is a definite peak at $\delta 3.2$ in Figure 6, which is just visible in Figure 3. The region from $\delta 1.2$ to 1.8 also is richer and more intense. Despite these significant differences, the two spectra retain a strong familial resemblance, as if Figure 6 is a younger (less mature) version of Figure 3. The 2D COSY spectrum of sample 1424 (Figure 7) has many more peaks in the block representing couplings between saturated protons $(\delta 1-3)$, and there are more cross peaks in other regions than in the simple spectrum illustrated in Figure 4. We believe that sample 1424 indeed represents a younger version of Indonesian fossil resin, traditionally associated with the term "copal."

We had a commercial sample (270) labeled "dammar," provided by G. O. Poinar Jr. Its ${ }^{13} \mathrm{C}$ spectra (Figure 8) bear close resemblance to those of sample 1424 (Figure 5), but with additional fine structure. The three peaks between $\delta$ 16 and 28 are still present, but with slightly different relative intensities. The 


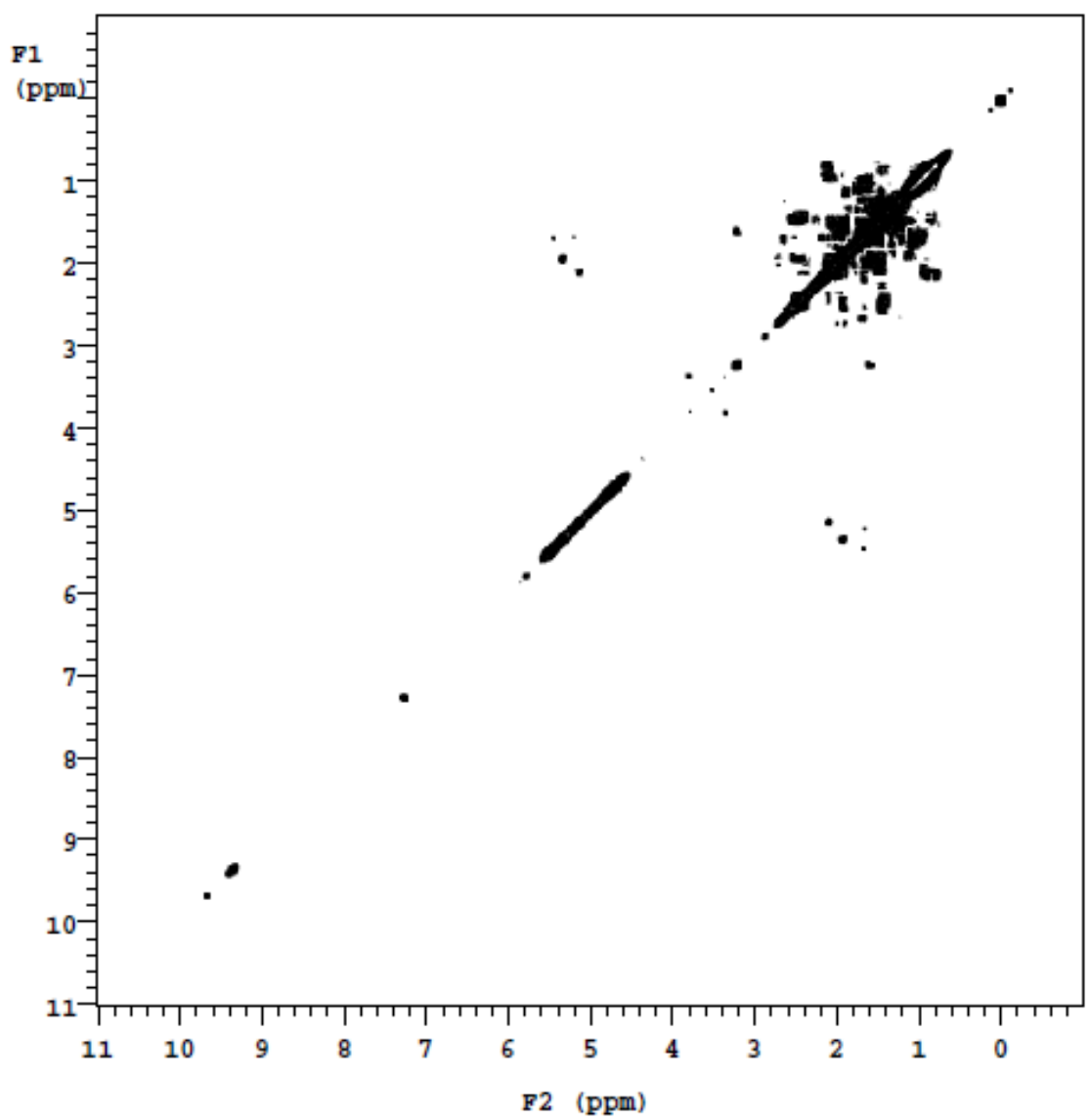

Figure 7. The 2D COSY spectrum of green copal gum from Lampung, South Sumatra, Indonesia (sample no. 1424) in chloroform- $d$.

two peaks at $\delta 37$ and 40 in Figure 8 are very similar to those in Figure 5. Now the broad peak at $\delta 48$ in Figures 2 and 5 has been replaced by a pair of peaks at $\delta 48$ and 52 (again, really the addition of a new peak). Thus the dammar sample continues the increased complexity seen in the spectra of sample 1424 compared with those of sample 1418. Our commercial dammar sample is less mature and younger than the other samples.

The $1 \mathrm{D}{ }^{1} \mathrm{H}$ spectrum of the dammar sample (no. 270) (Figure 9) is very similar to that of the green copal (1424) (Figure 6). The lower intensity peaks in the alkane region ( $\delta 1.2-1.5$ and 1.8-2.4) are nearly identical in the two spectra. The high intensity alkane peaks $(\delta 0.7-1.2$ and 1.6-1.8) include new peaks. The alkenic regions are different, but the peak at $\delta 5.5$ still is present. The aromatic 


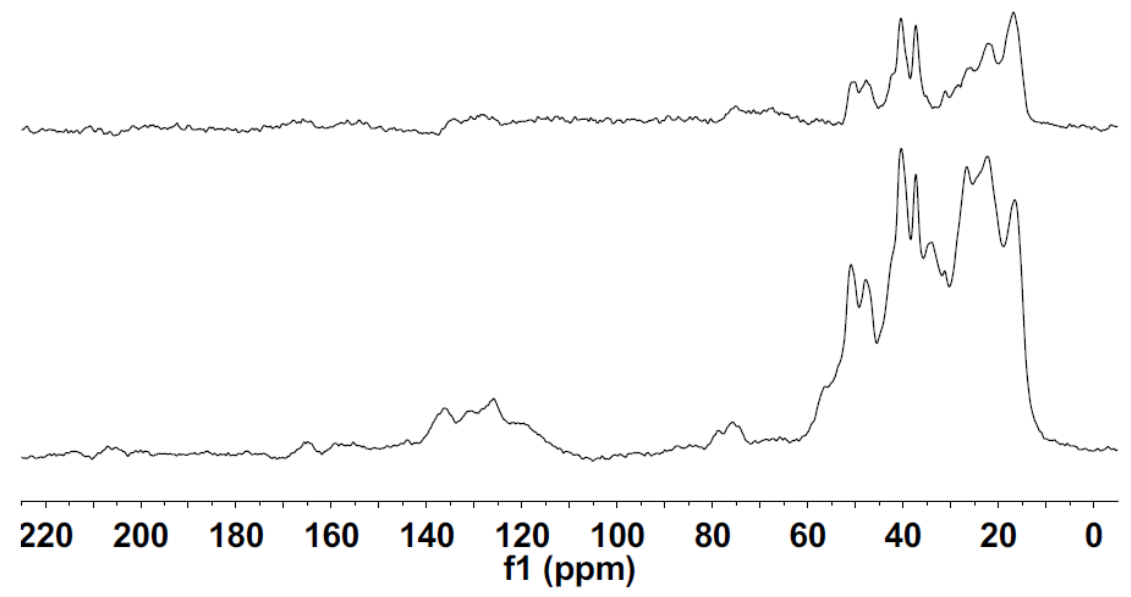

Figure 8. The solid state ${ }^{13} \mathrm{C}$ spectrum of dammar (sample no. 270) with normal decoupling (lower) and with dipolar dephasing (upper).

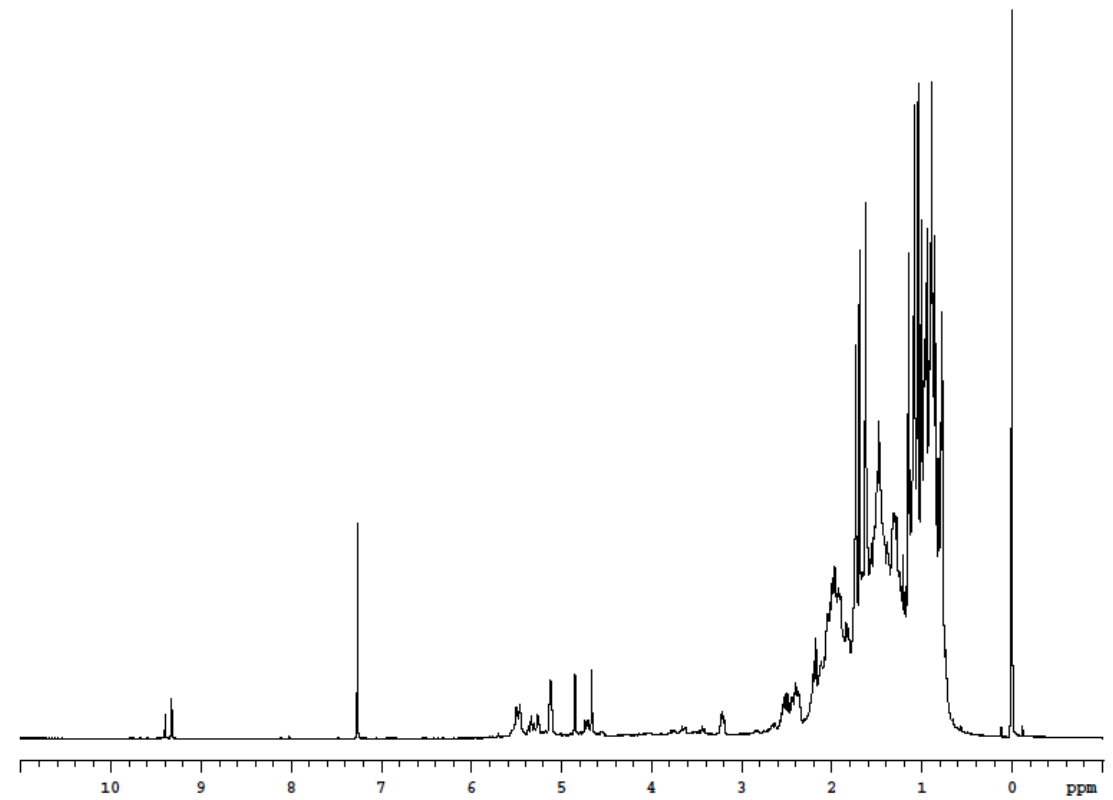

Figure 9. The $1 \mathrm{D}{ }^{1} \mathrm{H}$ spectrum of dammar (sample no. 270) in chloroform- $d$.

region is empty and, as with sample 1424 , there are aldehydic peaks at $\delta$ 9.3-9.5. The largest cross peak in the 2D COSY spectrum (Figure 10) is that at $(2.0,5.3)$, in common with the Indonesian ambers and copal. 


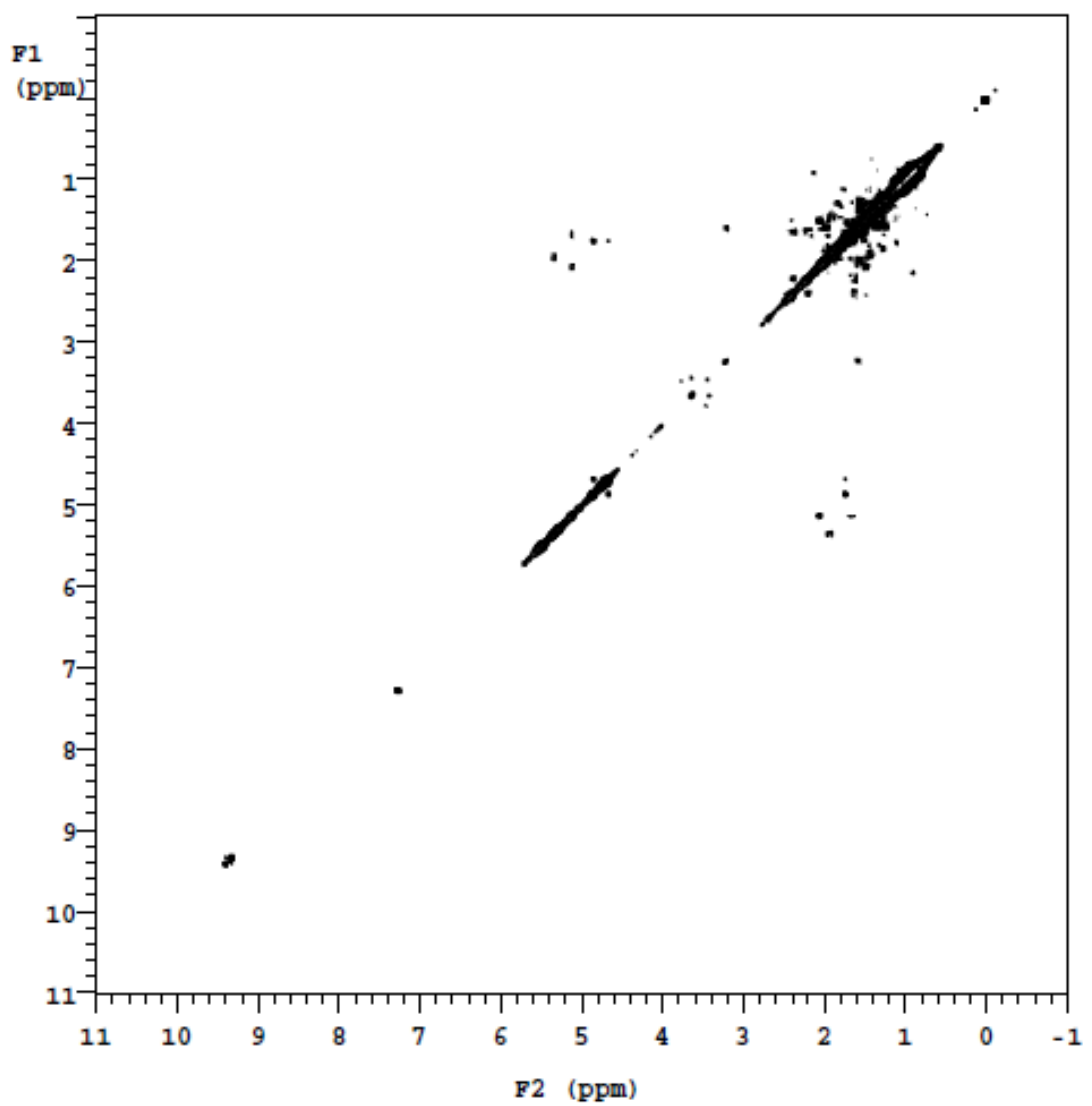

Figure 10. The 2D COSY spectrum of dammar (sample no. 270) in chloroform- $d$.

In our study of rosid exudates (Lambert et al., 2013), we examined the NMR spectra of 50 members of the family Dipterocarpaceae, of which 48 were resins. All genera and species exhibited very similar spectra, which we divided into two classifications, distinguished by peak breadth. The spectra of sample 1424 and of the dammar sample are similar to those of the group with sharper peaks for both ${ }^{13} \mathrm{C}$ and ${ }^{1} \mathrm{H}$ spectra. Figure 11 illustrates the ${ }^{13} \mathrm{C}$ spectra for the species Shorea hopeifolia (sample 789). Both modes of decoupling gave spectra closely resembling those of green copal (1424) and of dammar (270). Similar resemblances were found in the $1 \mathrm{D}{ }^{1} \mathrm{H}$ spectra, illustrated in Figure 12 for the same species (Shorea hopeifolia), including the alkenic peak at $\delta 5.5$ and the aldehydic peaks at $\delta$ 9.3. The COSY spectrum (Figure 13) is similar to that of dammar but with additional cross peaks. 


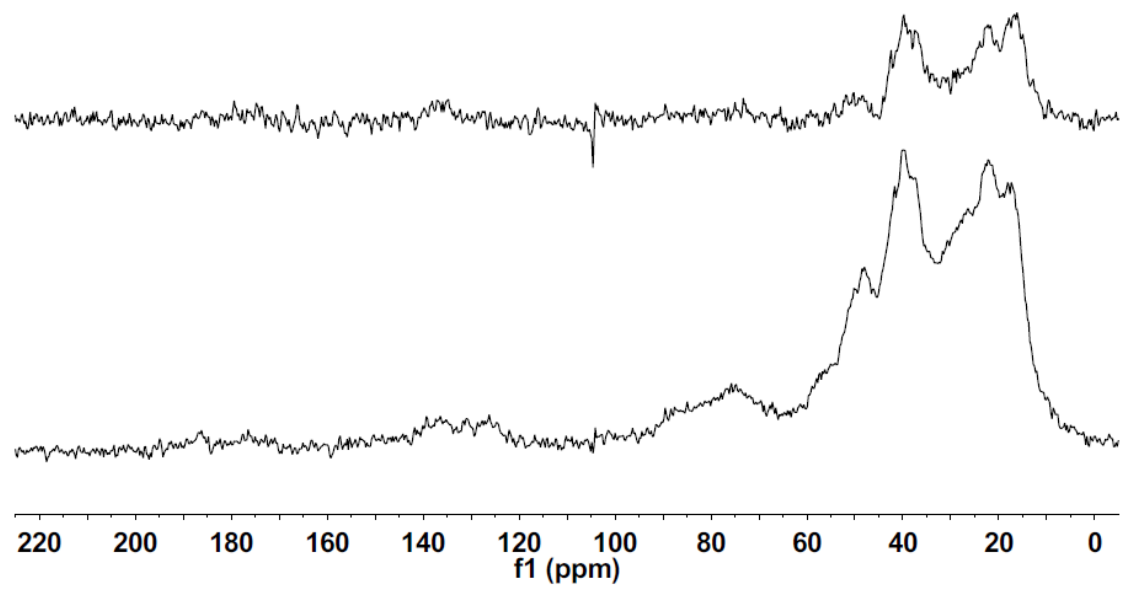

Figure 11. The solid state ${ }^{13} \mathrm{C}$ spectrum of the resinous exudate from Shorea hopeifolia (sample no. 789) with normal decoupling (lower) and with dipolar dephasing (upper).

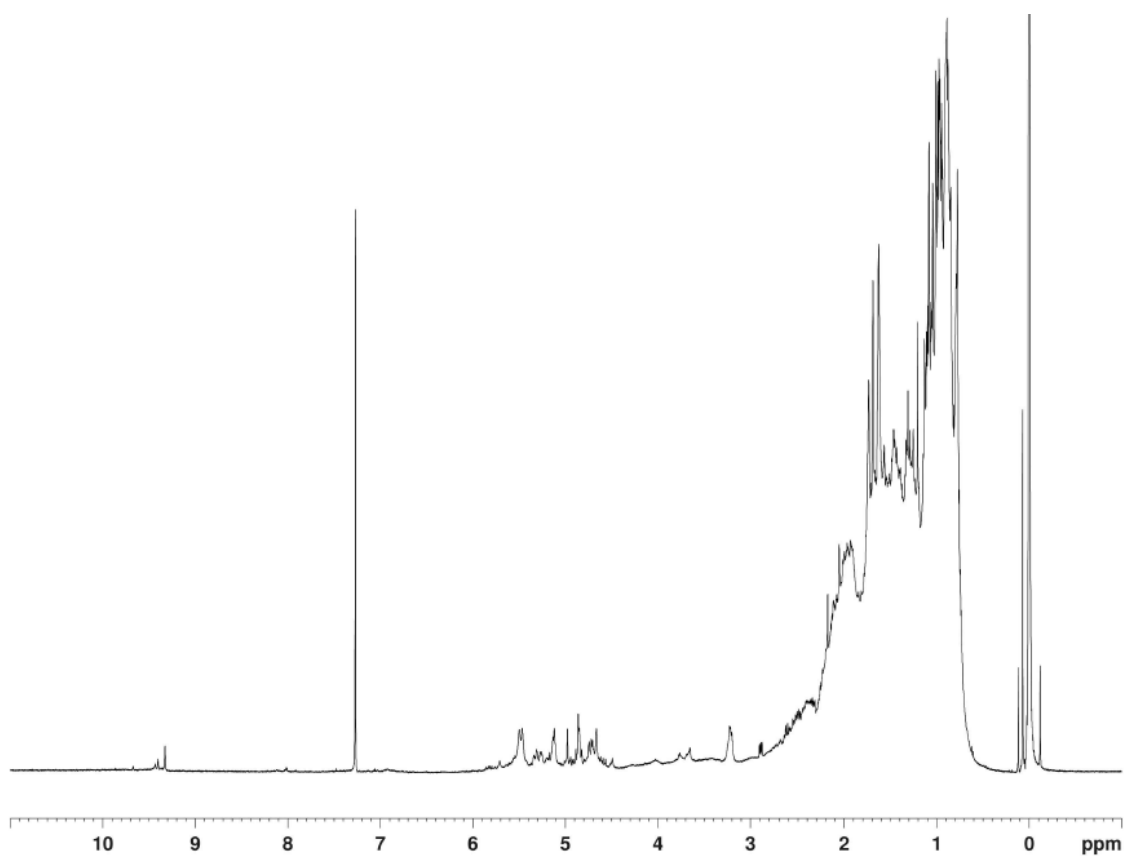

Figure 12. The $1 \mathrm{D}{ }^{1} \mathrm{H}$ spectrum of the resinous exudate from Shorea hopeifolia (sample no. 789) in chloroform- $d$. 


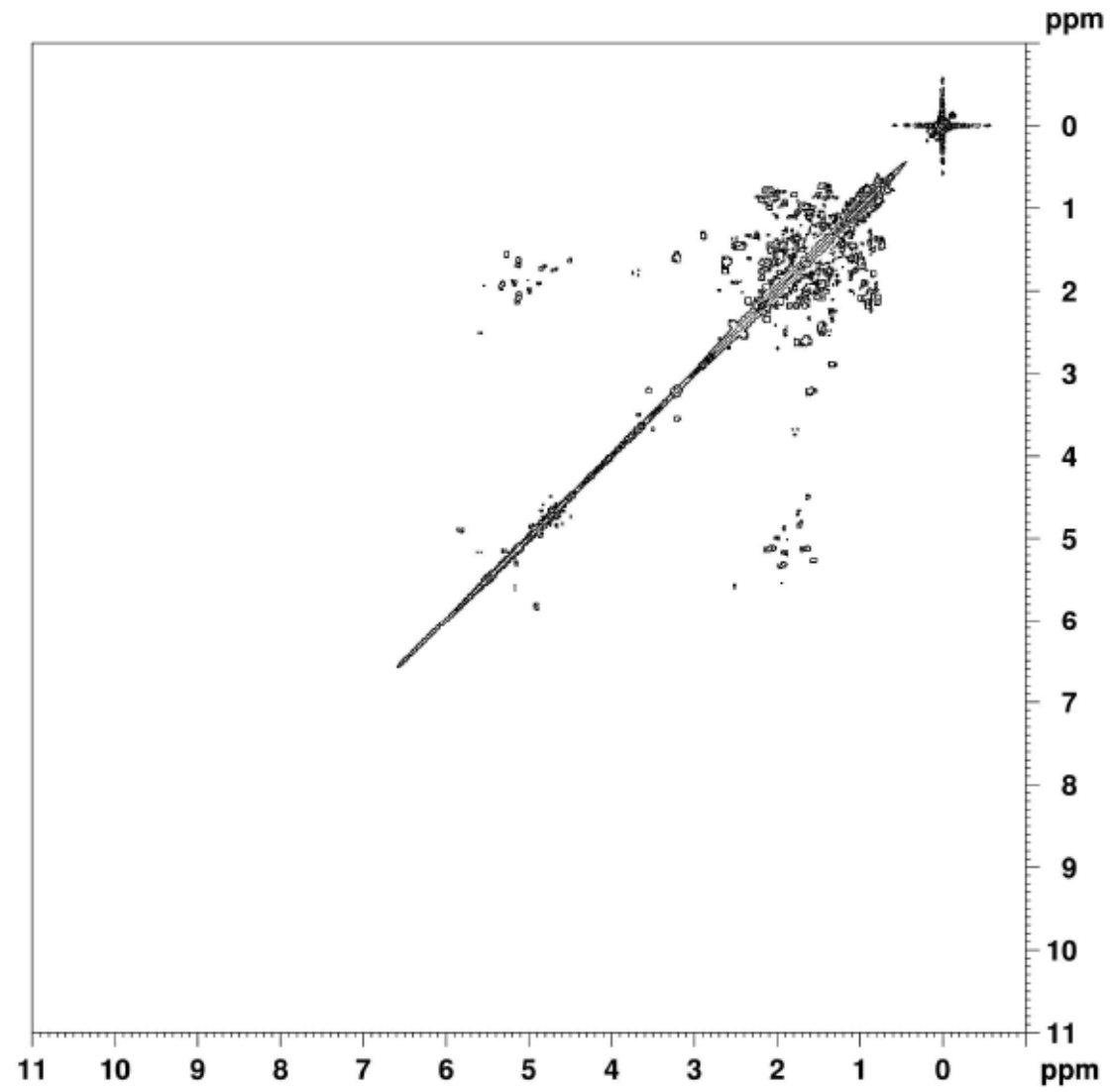

Figure 13. The 2D COSY spectrum of the resinous exudate from Shorea hopeifolia (sample no. 789) in chloroform- $d$.

\section{Conclusions}

We have examined 19 alleged samples of amber from Indonesia, Malaysian Borneo, and Papua New Guinea. Characterization by solid state ${ }^{13} \mathrm{C}$ NMR spectroscopy indicates that all these samples but one belong to the NMR amber classification of Group B (mass spectrometric Class II). The single Indonesian exception, labeled green copal, gave both ${ }^{13} \mathrm{C}$ and ${ }^{1} \mathrm{H}$ spectra characteristic of an appreciably less mature material. Spectra of a commercial dammar sample and of a sample of a typical modern dipterocarp resin, Shorea hopeifolia, closely resemble the spectra of green copal but with greater spectral complexity. The spectral series (Figures 2, 5, 8, and 11 for ${ }^{13} \mathrm{C}$ spectra and Figures 3, 6, 9, and 12 for $1 \mathrm{D}{ }^{1} \mathrm{H}$ spectra) exhibit a continuity that can be attributed to the maturation or degradation process from the present to the Miocene period, as illustrated in Figure 14 for the ${ }^{13} \mathrm{C}$ spectra with normal decoupling. This continuity provides 

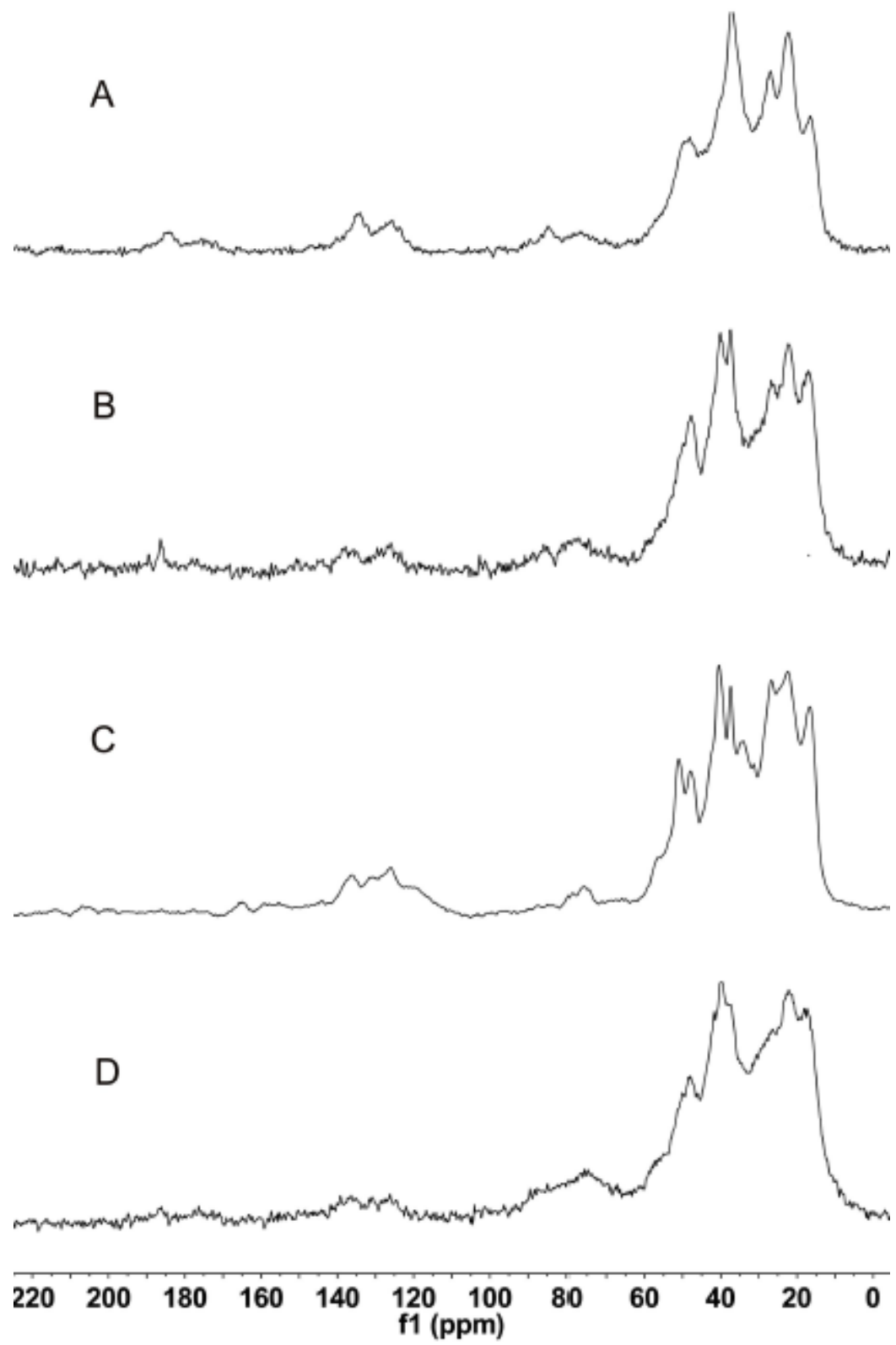

Figure 14. The solid state ${ }^{13} \mathrm{C}$ spectra of (top to bottom) samples 1418 (amber from Central Sumatra, A), 1424 (green copal amber from South Sumatra, B), 270 (commercial dammar, C), and 789 (modern Shorea hopeifolia, D) with normal decoupling. 
further support that Indonesian amber came from ancient dipterocarp forests. The similarity of the spectra from several modern Dipterocarpaceae genera (Dipterocarpus, Hopea, Shorea, Vateria, and Vatica) (Lambert et al. 2013) prevents further designation based on genus. The presence of Group B ambers in North America implies that similar, now-extinct species related to the Dipterocarpaceae existed in the Northern Hemisphere during the general time of the Lower Eocene.

\section{Literature Cited}

Anderson, K. B. and J. C. Crelling (Editors). 1995. Amber, Resinite, and Fossil Resins. ACS Symposium Series. No. 617. American Chemical Society. Washington, District of Columbia, USA. 297 pp.

Anderson, K. B and J. V. Muntean. 2000. The nature and fate of natural resins in the geosphere. Part X. Structural characteristics of the macromolecular constituents of modern Dammar resin and Class II ambers. Geochemical Transactions 1(March). http://dx.doi.org/10.1186/14674866-1-1

Anderson, K. B. and R. E. Winans. 1991. Nature and fate of natural resins in the geosphere. I. Evaluation of pyrolysis-gas chromatography mass spectrometry for the analysis of natural resins and resinites. Analytical Chemistry 63:2901-2908. http://dx.doi.org/10.1021/ac00024a019

Beck, C. W. 1986. Spectroscopic investigations of amber. Applied Spectroscopy 22: 57-110. http://dx.doi.org/10.1080/05704928608060438

Brackman, W., K. Spaargaren, J. P. C. M. Van Dongen, P. A. Couperus, and F. Bakker. 1984. Origin and structure of the fossil resin from an Indonesian Miocene coal. Geochimica Cosmochimica Acta 48:2483-2487. http://dx.doi.org/10.1016/0016-7037(84)90299-0

Fraquet, H. 1987. Amber. Butterworths. London, England, United Kingdom. 176 pp.

Grimaldi, D. A. 2003. Amber: Window to the Past. Harry N. Abrams. New York, NY, USA. 216 pp.

Lambert, J. B. and J. S. Frye. 1982, Carbon functionalities in amber. Science 217: 55-57. http://dx.doi.org/10.1126/science.217.4554.55

Lambert, J. B., J. S. Frye, and G. O. Poinar. 1990. Analysis of North American amber by carbon-13 NMR spectroscopy. Geoarchaeology 5: 43-52. http://dx.doi.org/10.1002/gea.3340050105

Lambert, J. B., S. C. Johnson, G. O. Poinar, Jr., and J. S. Frye. 1993. Recent and fossil resins from New Zealand and Australia. Geoarchaeology 8:141-155. http://dx.doi.org/10.1002/gea.3340080206

Lambert, J. B., S. C. Johnson, and G. O. Poinar, Jr. 1995. Resin from Africa and South America: criteria for distinguishing between fossilized and recent resin based on NMR spectroscopy. pp. 193-202. In, Anderson, K. B., and J. C. Crelling (Editors). Amber, Resinite, and Fossil Resins. ACS Symposium Series No. 617. American Chemical Society, Washington, District of Columbia, USA. 297 pp.

Lambert, J. B., Y. Wu, and J. A. Santiago-Blay. 2005. Taxonomic Relationships Revealed by Nuclear Magnetic Resonance Spectroscopy of Plant Resins and Gums. Journal of Natural Products 68:635-648. http://dx.doi.org/10.1021/np050005f

Lambert, J. B., J. A. Santiago-Blay, and K. B. Anderson. 2008. Chemical signatures of fossilized resins and recent plant exudates. Angewandte Chemie, International Edition 47:9608-9616. http://dx.doi.org/10.1002/anie.200705973

Lambert, J. B., C. Y.-h. Tsai, M. C. Shah, A. E. Hurtley, and J. A. Santiago-Blay. 2012. Distinguishing amber classes by proton magnetic resonance spectroscopy. Archaeometry 54: 332-348. http://dx.doi.org/10.1111/j.1475-4754.2011.00625.x

Lambert, J. B., E. W. Donnelly, E. A. Heckenbach, C. L. Johnson, M. A. Kozminski, Y. Wu, and J. A. Santiago-Blay. 2013. Molecular classification of the natural exudates of the rosids. Phytochemistry 94:171-183. http://dx.doi.org/10.1016/j.phytochem.2013.06.013

Langenheim, J. H. 2003. Plant Resins. Timber Press. Portland, Oregon, USA. 586 pp. 
Mills, J. S., and R. White. 1994. The Organic Chemistry of Museum Objects. Second Edition. Butterworth-Heinemann, Oxford, UK. 206 pp.

Nassau, K. 1983. The Physics and Chemistry of Color: The Fifteen Causes of Color. Wiley, New York, USA. $454 \mathrm{pp}$.

Nussinovich, A. 2010. Plant Gum Exudates of the World: Sources, Distribution, Properties, and Applications. CRC Press, Boca Raton, Louisiana, USA. 401 pp.

Poinar, G. E., and R. Poinar, 1994. The Quest for Life in Amber. Helix Addison Wesley. Reading, Massachusetts, USA. 219 pp.

Rice, P. C. 2006. Amber: The Golden Gem of the Ages. Fourth Edition. AuthorHouse Bloomington, Indiana, USA. $289 \mathrm{pp}$.

Stout, S. A. 1995. Resin-derived hydrocarbons in fresh and fossil Dammar resins and Miocene rocks and oils in the Mahakam Delta, Indonesia. pp. 42-75. In, Anderson, K. B., and J. C. Crelling (Editors). Amber, Resinite, and Fossil Resins. ACS Symposium Series No. 617. American Chemical Society. Washington, District of Columbia, USA. 297 pp.

van Aarssen, B. G. K., H. C. Cox, P. Hoogendoorn, and J. W. de Leeuw. 1990. A cadinene biopolymer in fossil and extant Dammar resins as a source for cadinanes and bicadinanes in crude oils from South-East Asia. Geochimica Cosmochimica Acta 54:3021-3031. http://dx.doi.org/10.1016/0016-7037(90)90119-6 